UDC 378.02:37.016

DOI: $10.23951 / 2782-2575-2021-2-45-56$

\title{
REDESIGNING AN UNDERGRADUATE RUSSIAN LANGUAGE UNIT: REFLECTIONS ON ALIGNING DEPARTMENTAL PEDAGOGIC OBJECTIVES WITH THE NEW TEACHING PROGRAMME AND ASSESSMENT
}

\section{Elena McNeilly}

\author{
University of Bristol Faculty of Arts School of Modern Languages Department of Russian
}

In this paper, we look into how the new structure of the final-year undergraduate language assessment introduced by the School of Modern Languages (SML) at the University of Bristol (UoB) has affected the teaching on the final-year programme in the Department of Russian.

This paper tests whether the intended learning outcomes, the content of the course, teaching on the individual modules, the learning resources and the new assessment can be considered as 'constructively aligned', i.e., whether the Russian language teaching team working on the new course design succeeded in ensuring that "the learning objectives, the learning processes and the assessment mode and criteria relate systematically to each other".

We will also explore whether the new blended synchronous and asynchronous teaching fits into the redesigned curriculum and whether the teaching programme continues to address the development of students' discipline-related and transferable employability skills linked to the three areas of the Bristol Skills Network: knowledge and intellectual abilities; engagement and influence; personal effectiveness and wellbeing.

The key element of this research is the analysis of the anonymous student feedback questionnaire (SFQ) which includes qualitative questions related to all three written modules taught on the redesigned final year Russian language unit: the students were given an opportunity to analyse the quality and effectiveness of their learning on this unit.

Keywords: learning, teaching, and assessing; learning objectives; intended learning outcomes, unit and programme design; constructive alignment; blended learning, quality assurance; peer-assessment; feedback; discipline-related skills, transferable employability skills.

\section{Background and Focus (goals)}

In the 2019-2020 academic year, the School of Modern Languages (SML) introduced changes to the final-year language assessment, which in turn caused an overhaul of the Year 4 Russian Language Curriculum. All language departments within the SML were asked to adjust their final-year teaching programmes and the assessment regime to the new assessment format.

In the proposal for the new unit, the intended learning outcomes (ILOs) were left intact:

"By the end of this unit students will:

1. be proficient in the spoken and written language to degree standard.

2. be able to communicate fluently in the spoken language in both formal and informal registers.

3. have a high level of competence in using the written language in a range of tasks.

4. be sensitive to register and nuances of the language studied and will be able to reflect these in translation.

5. be able to demonstrate and reflect on their distinctive linguistic and cultural expertise by exploring its practical application in a range of educational and cultural contexts" [1]. 
It was, however, suggested that the assessment should change as follows: two separate examinations, Translation into the Foreign Language, and Composition, should be abolished and replaced with one written exam containing new elements testing ILOs 1, 3 and 5.

We should note that within the previous assessment structure, ILOs 1 and 5 were addressed through teaching Composition and Translation into Russian in a blended learning format. The final-year curriculum was designed in a way that students' learning experience and departmental teaching practices were linked to the preparation for the final exams, as well as to careers which many Russianists aspire to pursue, e.g., working for the diplomatic service, United Nations, and other high-profile international organisations where advanced Russian language skills are needed. Role descriptions for jobs at these institutions often require evidence of advanced translation and essay-writing/analytical skills in Russian, as well as transferable employability skills, e.g., communicating and influencing, time management, being a team player, critical thinking, and problem solving.

In 2019, it became clear that, with two examinations having been taken off the final-year assessment, the Russian language unit required significant redesigning over the summer to get the unit ready for teaching in the new academic year.

Following a series of departmental discussions, we decided that Translation into Russian was to be replaced by Guided Writing comprising a) Mediation/Paraphrase from English into Russian, and b) Précis. Both skills are often required in various careers and are tested as part of an interview when Bristol graduates apply for jobs listed in the paragraph above.

In this paper, we have been focusing on seeking the answers to the following questions:

- Can the redesigned individual language modules address the development of skills that are linked to the unit's intended learning outcomes, but which are no longer directly assessed?

- How can we ensure that crucial discipline-related skills are still addressed as part of students' learning experience within the updated curriculum?

- How will we know that the learning objectives, teaching practices and the new assessment structures have been constructively aligned?

We will also look into the students' perception of whether they have been developing transferable employability skills as part of their learning process.

To evaluate the effectiveness of the redesigned curriculum and assessment, we will analyse a survey completed by the students. The survey aimed to assess the quality of the learning process, the effectiveness of our teaching, the quality of the academic support given to the students on the unit, and to see whether we succeeded in aligning the pedagogic objectives of the Russian department with the new curriculum and assessment.

\section{Positioning the question in the learning and teaching in Higher Education (HE) Literature}

As academics, we are well aware of the fact that the curriculum of any particular course, the teaching methods, and the assessment procedures need to be interrelated and compatible. Biggs argues that "when there is alignment between what we want, how we teach and how we assess, teaching is likely to be much more effective" [2: 27]. Norton supports this: "If we accept the principles of constructive alignment expounded by Biggs, then we should start curriculum design with the question of 'What is it that I want my students to have learned by the end of this course, module, or programme?' frequently referred to as the learning outcome. The concomitant question is 'How will I know that they have learned it'?" [3: 93]

When redesigning the new unit, we had in mind the questions set out in the previous paragraph. We knew from experience that "what and how students learn depends to a major extent on how they think they will be assessed" [2: 140-141]. 
Biggs's analysis of the criterion-based assessment package [ibid: 167] fits well into the intended model of assessment for our unit, which incorporates criterion-referenced formative peer-assessed tasks to monitor individual progress throughout the unit, and teacher-controlled summative assessment in the form of a final-year examination.

Peer feedback was an essential part of the Translation module within the old, pre-2019 language unit. When redesigning the unit, we needed to ensure that peer feedback and elements of peer assessment were preserved. "There are great opportunities and advantages, in terms of understanding and engagement, to learners providing feedback on and assessing each other's work. Using and/or developing assessment criteria takes students deeper into their learning and allows for feedback and reflection on learning and the sharing of what new meaning appears" [4: 2].

Our approach of incorporating the broader use of the discussion forum on Blackboard in course design is supported in Lea's article where she argues that virtual learning environments (VLEs) offer "students the opportunity for electronic debate and discussion and, additionally, providing a permanent record of these which can be accessed repeatedly by students throughout their studies" [5: 11].

In this paper, we refer to Priorities of the UoB Education Strategy [6: 3] and relate to the author's own reflections on teaching practice as the methods and approaches we propose within the redesigned curriculum are built on the author's previous experience which is outlined and analysed in the recently published paper [7].

\section{Methods and analysis}

To assess the effectiveness of the redesigned curriculum, we have used a mixture of methodologies including the analysis of the results of formative assignments, peer observation of teaching in the department, followed by sharing feedback on the observed teaching with colleagues within the teaching team.

The key component of the author's research has been the analysis of the anonymous student feedback questionnaire (SFQ). We aimed for the survey in question to be part of the students' "learning process rather than a commentary on that process" and, as well as seeking feedback on whether objectives were being achieved, we wanted to provide the students with "an opportunity to critique those objectives" [8: 11].

The SFQ includes qualitative questions related to all three written modules taught within the redesigned RUSS30001 unit: the students were given an opportunity to analyse the quality of their learning on this unit.

The students filled in the questionnaire in weeks 19-20 of the academic year: by this time, they have completed several formative written assignments working in pairs with a partner, as well as one individual progress check comprising a written task on which they received feedback and feedforward from the tutors. It was also peer assessed in the Guided Writing/Paraphrase module. By week 19, the students will have been able to evaluate what and how they learn. They will have acquired perception of how well they are progressing on this unit, as well as what their expectations are in relation to the potential exam grade.

The questionnaire has been designed as a formative quality assurance tool: "...used formatively, SFQs make eminent sense where questions are tailored to specific courses on aspects on which feedback is required" [2: 278].

We focused on investigating the learning experience of the students across several areas:

a) Clarity of the learning objectives and the assessment criteria across the three written modules. 
b) The quality of teaching and the quality of interaction with the tutors.

c) The usefulness of feedback (or, frequently, feedforward) on formative assignments received from the tutors, as well as peer assessment and peer feedback.

d) The quality of learning across the three written modules.

f) What transferable employability skills are being developed on this unit, in our students' opinion.

\section{Results and discussion}

$29 \%$ of the cohort completed the questionnaire (11 of 38 students) [table 1]. Most of the responses show how the students evaluate the new unit design, the teaching methods, their learning experience, and the formative assessment structure.

Q1-2 identify whether the students felt that learning objectives and the assessment criteria were made clear at the start of the course.

The answers were unanimously positive. They varied from a simple 'yes' to more detailed comments confirming clarity of the objectives and the assessment criteria on the individual modules of the unit. Student 9 noted that they "... have found the exercises where we have had to mark a piece of work ourselves very helpful in terms of becoming familiar with the marking criteria." This matches exactly the goal we were pursuing as we wanted the students to get to know the newly designed assessment criteria through marking a practice piece completed by their partners.

Q3-6 evaluate the teaching practices, academic advice, and the quality of interaction with the tutors. Respondents showed their satisfaction with the teaching and the support they received from their tutors in all three modules. The answers vary from brief responses to nuanced comments linked to specific modules

The analysis of the students' evaluation of the clarity of the unit objectives and the marking criteria, the teaching and learning processes, as well as the quality of interaction with their tutors (Q1-6), confirms that the learning objectives and teaching practices applied on the unit are aligned.

Q7 checks if learning-related activities reinforce the learning objectives of the unit. Most respondents focused on activities linked directly to their assessment, e.g., "Going over Russian grammar" or 'Regular speaking practice'. We were, however, pleased to see that Students 2 and 9 reflected on the development of transferable skills and the fact that they are being prepared not just for exams but also for what lies ahead after graduating.

Q8 evaluates students' understanding of how the feedback from the tutors, as well as peer feedback practised in the Guided Writing (Paraphrase) module, helps the students prepare for exams. Responses confirm that the students find tutors' feedback helpful, encouraging and motivating. Respondents note the usefulness of the peer-assessment exercise as it helped in preparation for the exam.

The responses to Q9 indicate that the majority identify the development of language-related skills as well as exam preparation to be the most useful aspects. One respondent went further: "I think the most useful aspect of the course is the collaborative aspect because I have learnt not just from my tutors but also my other course mates as well." This comment refers to the online discussions and peer-assessment practice, the elements that are linked to the blended approach within the guided writing module.

Based on the responses to Questions 7-9, it is reasonable to conclude that students' learning experience is aligned with the formative assessment structure.

The answers to Q10 suggest that the majority of respondents value teamwork, a major component of the Guided Writing/Paraphrase module, which comprises working in pairs, online 
forum discussions, working in breakout rooms online. Student 4 noted that they enjoy " $a$ very friendly and convivial atmosphere" of the Paraphrase tutorials, and Student 3 mentioned that they value "personal relationships with teachers/course-mates". This confirms that our principle of maintaining a friendly and encouraging atmosphere in the classroom helps the students to stay motivated and engaged in their learning.

Q11-12 identify in what way the unit changed students as learners and asks them to reflect on what transferable skills they have developed. Three respondents have mentioned that their critical thinking and problem-solving skills have improved, although

the most common skills referred to in the responses are time management, communication, and teamwork.

Q13-14 seek to elicit additional suggestions to help strengthen the course. Responses from students 4, 6 and 11 include valid points which will help to enhance our teaching practice, e.g., suggestions to teach Précis and Paraphrase in alternate weeks or to use a broader range of resources, including topical films. These suggestions have been considered by the teaching team in preparation for the next academic year. Student 10 expresses the view that they are not sure if "learning to translate/paraphrase into Russian is a very useful skill for the future." This made us think that in the introductory class, we should provide more examples and insight into how the skills taught on the unit could relate to students' future careers.

Table 1

\section{Questionnaire}

Anonymous student feedback on the final-year Russian language written modules:

E-R Guided Writing/Paraphrase; Precis, and Writing (mini-essay)

\begin{tabular}{|c|c|}
\hline Question 1 & $\begin{array}{l}\text { Were the learning objectives identified and expectations made clear as far as the course } \\
\text { information was concerned? }\end{array}$ \\
\hline Student 1 & Yes \\
\hline Student 2 & Yes \\
\hline Student 3 & Yes \\
\hline Student 4 & Yes \\
\hline Student 5 & Yes \\
\hline Student 6 & Yes, the learning objectives and expectations for the course were made clear at the start of the year \\
\hline Student 7 & $\begin{array}{l}\text { Paraphrase: yes, Precis: yes, Writing: yes; in all three units learning objectives are clarified from the } \\
\text { outset and we consistently return to this throughout the course, particularly in the case of Writing and } \\
\text { Paraphrase }\end{array}$ \\
\hline Student 8 & Yes \\
\hline Student 9 & Yes, very clear \\
\hline Student 10 & $\begin{array}{l}\text { Yes, like every year, the Russian department has made everything very clear. The zoom meeting we } \\
\text { had clarifying assessments was particularly helpful }\end{array}$ \\
\hline Student 11 & Yes \\
\hline Question 2 & Were the assessment criteria made clear? \\
\hline 1 & Mostly yes \\
\hline 2 & Yes \\
\hline 3 & Yes \\
\hline 4 & Yes \\
\hline 5 & Yes, it is displayed clearly on the course's Blackboard site \\
\hline 6 & $\begin{array}{c}\text { Paraphrase: yes, Precis: yes, Writing: yes. The assessment criteria in all three units are extremely } \\
\text { clear }\end{array}$ \\
\hline 7 & Yes \\
\hline 8 & Yes, very clear \\
\hline 9 & $\begin{array}{l}\text { Yes - I have found the exercises where we have had to mark a piece of work ourselves very helpful } \\
\text { in terms of becoming familiar with the marking criteria }\end{array}$ \\
\hline
\end{tabular}


Education \& Pedagogy Journal. 2021. 2 (2)

\begin{tabular}{|c|c|}
\hline 10 & Yes \\
\hline 11 & Yes \\
\hline Question 3 & Have you been receiving helpful academic advice during your studies on this unit? \\
\hline Student 1 & Yes \\
\hline Student 2 & Yes \\
\hline Student 3 & Yes \\
\hline Student 4 & Definitely \\
\hline Student 5 & Yes, for the most part. The advice/feedback has generally been useful for me \\
\hline Student 6 & $\begin{array}{l}\text { Paraphrase: yes, Precis: yes, Writing: yes; in all three courses, academic advice is not only prompt, } \\
\text { but extremely helpful. Ilona marks essays with an astounding turnaround for such a big cohort, and } \\
\text { so too is Elena's feedback. I particularly like the way that Paraphrase Анализ is based off Elena's } \\
\text { collective feedback. This allows access to new vocabulary (for example, when we discuss in class) } \\
\text { but also some of the trickier sections }\end{array}$ \\
\hline Student 7 & Yes \\
\hline Student 8 & Yes, I am impressed at the level of guidance throughout the academic year \\
\hline Student 9 & $\begin{array}{c}\text { Yes, absolutely - I have had more feedback in this unit than any other in my university career - the } \\
\text { Russian department is always very good at this }\end{array}$ \\
\hline Student 10 & Yes, but I don't think it's been anything new to us after our first and second years \\
\hline Student 11 & Yes \\
\hline Question 4 & Has the academic advice been timely? \\
\hline Student 1 & Yes always \\
\hline Student 2 & Yes \\
\hline Student 3 & Yes \\
\hline Student 4 & Yes \\
\hline Student 5 & $\begin{array}{l}\text { Yes, teachers are generally good at returning pieces of work. However, I would say that the deadlines } \\
\text { for some formative pieces of work are quite hard to meet at times, especially when having to deal } \\
\text { with other summative deadlines that are deemed to be more important. I especially think that late } \\
\text { work should still be marked because, in some cases, students are not always able to balance these } \\
\text { formative assessments as well as more important essays/summative assessments }\end{array}$ \\
\hline Student 6 & $\begin{array}{c}\text { Paraphrase: yes, Precis: yes, Writing: yes. As I have mentioned above, all academic advice has been } \\
\text { extremely well timed. Quite simply put, the sheer level of feedback and the rapid time we get advice } \\
\text { is something that is not replicated in other units where it can take }+2 \text { weeks for feedback on one } \\
\text { essay }\end{array}$ \\
\hline Student 7 & Yes \\
\hline Student 8 & Yes \\
\hline Student 9 & $\begin{array}{c}\begin{array}{c}\text { Absolutely - I have been so grateful for the amount of time my Russian teachers have put into giving } \\
\text { me feedback on time }\end{array} \\
\end{array}$ \\
\hline Student 10 & Yes \\
\hline Student 11 & Yes \\
\hline Question 5 & $\begin{array}{l}\text { How would you describe the quality of interaction with the tutor/tutors } \\
\text { on this unit? }\end{array}$ \\
\hline Student 1 & Very high and personalised to my needs. \\
\hline Student 2 & Fantastic. All the Russian teachers show a genuine interest in your progress. \\
\hline Student 3 & Good. \\
\hline Student 4 & $\begin{array}{l}\text { Excellent. We have regular contact with tutors, and they are very responsive to emails. Even at } \\
\text { weekends! }\end{array}$ \\
\hline Student 5 & $\begin{array}{l}\text { Good interaction: my tutors usually reply fairly quickly to my emails. In addition, they } \\
\text { let us know in advance of any changes to the lessons/upcoming tests in class etc. }\end{array}$ \\
\hline Student 6 & $\begin{array}{l}\text { Paraphrase: extremely high, Precis: high, Writing: high. All three units offer an extremely high } \\
\text { quality of interaction, but Paraphrase particularly excels at this. Elena's classes provide an } \\
\text { opportunity to not only interact with her, but with other students to } \\
\text { compare and contrast answers. All three tutors have repeatedly gone above and beyond } \\
\text { in terms of interaction }\end{array}$ \\
\hline Student 7 & Excellent - I feel well supported by my tutors for this unit \\
\hline
\end{tabular}


Elena McNeilly. Redesigning an Undergraduate Russian Language Unit: Reflections on Aligning...

\begin{tabular}{|c|c|}
\hline Student 8 & High quality \\
\hline Student 9 & $\begin{array}{l}\text { The best - I feel like I can ask anything, and I always receive any help I need. } \\
\text { Also, I feel like all the tutors in the Russian dept are really good at communicating } \\
\text { where you need to improve and are always supportive }\end{array}$ \\
\hline Student 10 & Good, I've felt able to contact my tutors for help if I need it \\
\hline Student 11 & Good \\
\hline Question 6 & Are the methods of teaching effective in helping you learn? \\
\hline Student 1 & Yes \\
\hline Student 2 & Yes \\
\hline Student 3 & Good \\
\hline Student 4 & Yes \\
\hline Student 5 & Yes \\
\hline Student 6 & $\begin{array}{l}\text { Paraphrase: yes, Precis: yes, Writing: yes. As I have mentioned above, I think Elena's анализ is } \\
\text { invaluable }\end{array}$ \\
\hline Student 7 & Yes \\
\hline Student 8 & Yes \\
\hline Student 9 & $\begin{array}{c}\text { Absolutely - I think that they are very good in preparing us not just for the exams but for life beyond } \\
\text { university, which I am very grateful for! }\end{array}$ \\
\hline Student 10 & Yes \\
\hline Student 11 & Yes \\
\hline Question 7 & Which activities on this course have reinforced the learning objectives? \\
\hline Student 1 & $\begin{array}{l}\text { In-class discussions, examples of exemplary work, feedback received from tutors, going over } \\
\text { Russian grammar }\end{array}$ \\
\hline Student 2 & $\begin{array}{l}\text { Completing translations in pairs is good because it promotes communication and thought about } \\
\text { specific parts of the work }\end{array}$ \\
\hline Student 3 & Weekly feedback \\
\hline Student 4 & $\begin{array}{l}\text { I found that for both the precis and paraphrase components of the course, it is really helpful that we } \\
\text { do one practice exercise every single week. I also have nothing but praise for Ilona's writing classes. } \\
\text { They are very well-structured, and the grammar work we do is extremely helpful in improving our } \\
\text { written work. I feel very well-prepared for the exam as a result of all } 3 \text { parts of the course. } \\
\text { Everything we do in our Russian language classes has a clear focus on the exam }\end{array}$ \\
\hline Student 5 & No answer \\
\hline Student 6 & $\begin{array}{c}\text { I cannot speak much to Precis as I have swapped to paraphrase now, but both Writing and Paraphrase } \\
\text { activities are structured to enhance learning objectives }\end{array}$ \\
\hline Student 7 & $\begin{array}{l}\text { Regular speaking practice } \\
\end{array}$ \\
\hline Student 8 & $\begin{array}{l}\text { The collaborative element of the course and discussion afterwards. The opportunity to mark other } \\
\text { peoples' work and learn from model translations }\end{array}$ \\
\hline Student 9 & $\begin{array}{l}\text { Working in groups and marking each other's work has been a great way to make sure that we are not } \\
\text { only ready for the exams but also for the workplace wherever we might end up after university }\end{array}$ \\
\hline Student 10 & $\begin{array}{l}\text { I like Ilona's classes because the discussion on the text in groups makes me think critically and } \\
\text { engage with the text and the grammar reviews are extremely helpful }\end{array}$ \\
\hline Student 11 & No answer \\
\hline Question 8 & $\begin{array}{l}\text { Have the formative assessment methods (your tutor's feedback on written practice pieces and } \\
\text { peer assessment/peer feedback) helped you in preparation for exams? If yes, how have these } \\
\text { helped? }\end{array}$ \\
\hline Student 1 & $\begin{array}{l}\text { Yes, they have shown me what I'm doing well and what I need to improve for next time; each time } \\
\text { I hand something in and receive feedback on it, I get to know what structure is required in the exam, } \\
\text { and how to get a good mark }\end{array}$ \\
\hline Student 2 & Yes, the feedback on language and format is always thorough and specific \\
\hline Student 3 & Extremely helpful \\
\hline Student 4 & $\begin{array}{l}\text { Definitely! Written feedback from tutors is always detailed and helpful. This is useful since it helps } \\
\text { me to notice patterns in the mistakes I'm making and improve as a result. The peer work we did in } \\
\text { Elena's paraphrase lessons was also useful, since it is good to get another student's perspective on } \\
\text { the work }\end{array}$ \\
\hline
\end{tabular}




\begin{tabular}{|c|c|}
\hline Student 5 & No answer \\
\hline Student 6 & $\begin{array}{l}\text { I have mentioned this above, but I simply cannot stress how much the Russian department provides } \\
\text { in terms of feedback. Having a marked piece of work every single week allows me to track my own } \\
\text { progress and gives me specific areas on which to improve. From feedback, I am able to develop my } \\
\text { grammar skills, pick out vocab I may have made mistakes on / didn't know before. Every piece of } \\
\text { work we do, to 'paraphrase' Elena, is in preparation for the exam and having feedback every single } \\
\text { week minimum is amazingly helpful. Although I may be a bit shaky in terms of my language, I know } \\
\text { that I will go into the exam with confidence in what I need to do }\end{array}$ \\
\hline Student 7 & $\begin{array}{l}\text { Yes. It has helped me to see where I have gone wrong and how I can improve for the exam. I also } \\
\text { appreciate the positive feedback and encouragement my tutors have offered me. I find this } \\
\text { motivating }\end{array}$ \\
\hline Student 8 & $\begin{array}{l}\text { Yes, they have helped in understanding the best phrases required for specific translations to render in } \\
\text { a more idiomatic way }\end{array}$ \\
\hline Student 9 & $\begin{array}{l}\text { Yes absolutely. I now know exactly what is expected from me and it has greatly increased my } \\
\text { confidence for the exam, because I know I can do it if I put my mind to it }\end{array}$ \\
\hline Student 10 & It's helped me to identify problem areas to address before the exams \\
\hline Student 11 & Definitely - they have pointed out the grammar areas I need to work on \\
\hline Question 9 & What is the most useful aspect of this course and why? \\
\hline Student 1 & Grammar revision for essay writing - so I know how to correctly form sentences which make sense \\
\hline Student 2 & $\begin{array}{c}\text { Guided writing (Paraphrase). Although it is the most challenging, it also offers various layers of } \\
\text { working. E.g., working through a translation with someone else, peer reviewing and then going over } \\
\text { the work in class }\end{array}$ \\
\hline Student 3 & Regular feedback \\
\hline Student 4 & $\begin{array}{c}\text { Ilona's writing classes, because I feel that my grammar still needs lots of improvement and we do } \\
\text { lots of grammar practice in those classes }\end{array}$ \\
\hline Student 5 & $\begin{array}{l}\text { Précis writing has been useful to get to grips with as I understand that this is an important skill for } \\
\text { some roles. In addition, recapping some key grammar points as well as some good phrases in the } \\
\text { writing class has been useful ahead of my preparation for this part of the exam }\end{array}$ \\
\hline Student 6 & $\begin{array}{l}\text { Writing: having an article every week has been extremely useful. I can take this information and pick } \\
\text { out vocab, useful phrases, statistics, and examples. Outside of language learning, I have learnt an } \\
\text { enormous amount about Russian life \& culture, particularly about modern Russia, which is not an } \\
\text { area I was previously particularly confident in! } \\
\text { Paraphrase: as I mention above, I think the most useful aspect of paraphrase is having an assessed } \\
\text { piece of work every week and the aнализ. Similarly, to writing, the articles we have to read provide } \\
\text { an insight into Russian culture and from this course I have drawn out some idiomatic expressions I } \\
\text { wouldn't have otherwise encountered }\end{array}$ \\
\hline Student 7 & $\begin{array}{c}\text { All aspects are useful in their own way - we practice a variety of different skills necessary for } \\
\text { language development in each class - I can't decide }\end{array}$ \\
\hline Student 8 & The opportunity to learn from others and improve \\
\hline Student 9 & $\begin{array}{l}\text { I think the most useful aspect of the course is the collaborative aspect because I have learnt not just } \\
\text { from my tutors but also my other course mates as well - whether that be vocabulary I haven't } \\
\text { encountered before, or just reinforcing grammar and good phrases }\end{array}$ \\
\hline Student 10 & $\begin{array}{l}\text { Yelena's precis class is really good; working with a Russian text and summarising it in Russian is a } \\
\text { great skill to learn and I engage with the text much better }\end{array}$ \\
\hline Student 11 & $\begin{array}{l}\text { The discussions about the mini-essays and articles in the writing classes were really informative and } \\
\text { helped to develop my ideas about Russia while also improving my language }\end{array}$ \\
\hline Question 10 & \begin{tabular}{|l|} 
What is the most enjoyable aspect of this course and why? \\
\end{tabular} \\
\hline Student 1 & $\begin{array}{l}\text { I enjoy the in-depth discussions in Paraphrase classes of different ways to go about translation as it } \\
\text { lets me hear other people's methods which I could employ in a following translation }\end{array}$ \\
\hline Student 2 & $\begin{array}{l}\text { I would not say any of the work is enjoyable as such, but I feel like I have improved my Russian } \\
\text { significantly and the feeling of progress is satisfying. This is a good thing. } \\
\text { I would rather the work was laborious, so the feeling of progress is greater }\end{array}$ \\
\hline Student 3 & Personal relationships with teachers/course mates \\
\hline Student 4 & Elena's paraphrase lessons because there was a very friendly and convivial atmosphere. \\
\hline
\end{tabular}




\begin{tabular}{|c|c|}
\hline Student 5 & $\begin{array}{l}\text { The most enjoyable aspects of the course have been the Political \& Economic Russian classes with } \\
\text { Elena, as I feel that it has helped me to further my knowledge about Russia and will undoubtedly be } \\
\text { helpful for my future career. } \\
\text { In addition, I have also enjoyed the précis writing and paraphrase classes as they have helped me to } \\
\text { have much more in-depth understanding of the Russian language and its syntax but, at the same } \\
\text { time, hugely widen my knowledge of key topic vocabulary }\end{array}$ \\
\hline Student 6 & $\begin{array}{l}\text { Writing: I think the most enjoyable aspect of writing is the class discussions we have. I think the way } \\
\text { that the class is structured to go through the article as a group and then split off into breakout rooms } \\
\text { is a fantastic way to approach the articles. It gives me confidence before speaking in smaller teams } \\
\text { and working in smaller groups is a nice way for me to express my own ideas and opinions. } \\
\text { Paraphrase: Working in pairs has been a very enjoyable aspect. I have learnt a lot from reading my } \\
\text { partner's work and the work of others. More generally, I think the structure of this unit has also been } \\
\text { very enjoyable. The set deadlines allow me to prioritise my work and structure my week effectively. } \\
\text { I also think that this unit has taught me a lot about how to manage my workload, especially when } \\
\text { working with another person and figuring out a time to collaborate }\end{array}$ \\
\hline Student 7 & No answer \\
\hline Student 8 & Again, the teamwork element is highly enjoyable \\
\hline Student 9 & $\begin{array}{l}\text { For me, the most enjoyable aspect is the quick pace - at first, I wasn't sure if I would enjoy the quick } \\
\text { turnarounds of work etc. but I have really got into the swing of them and feel very productive and } \\
\text { have been learning very fast }\end{array}$ \\
\hline Student 10 & $\begin{array}{l}\text { I really like Ilona's class; she's a great teacher and I always find that I learn a lot during } \\
\text { the hour }\end{array}$ \\
\hline Student 11 & No answer \\
\hline Question 11 & How has this unit changed you as a learner? \\
\hline Student 1 & I am forced to be more sociable and work as a team \\
\hline Student 2 & The intensity of the course has forced me to better manage my time \\
\hline Student 3 & Forced me to become more organised \\
\hline Student 4 & $\begin{array}{c}\text { I now use a wider range of online dictionaries and resources (e.g., Yandex perevodchik) which has } \\
\text { definitely improved my Russian }\end{array}$ \\
\hline Student 5 & No answer \\
\hline Student 6 & $\begin{array}{l}\text { As I mention below, this unit has changed me in terms of acquiring new skills of expressing myself } \\
\text { clearly and working with tight deadlines in a way that is respectful of other people's time. More } \\
\text { generally, I think my confidence has blossomed in this unit, not just as a learner, but as a person and } \\
\text { I will take this skill with me out into the world }\end{array}$ \\
\hline Student 7 & No answer \\
\hline Student 8 & I have expanded on my critical skills and communicative skills \\
\hline Student 9 & $\begin{array}{l}\text { I think I have become more open-minded as a learner - I am now much more willing to take } \\
\text { on tasks that, at first, I was not sure about, and I am certainly much more open to working } \\
\text { in a team }\end{array}$ \\
\hline Student 10 & $\begin{array}{l}\text { I'm better at time-management because of the volume of work we receive and this year especially } \\
\text { I've enjoyed working in pairs and groups because it's been so long since we've seen our classmates }\end{array}$ \\
\hline Student 11 & I think it's helped me see the benefit of teamwork \\
\hline Question 12 & $\begin{array}{l}\text { What transferable employability skills have you acquired while studying } \\
\text { on this course? }\end{array}$ \\
\hline Student 1 & $\begin{array}{l}\text { Time management, critical thinking, organisation skills, communication with team members, } \\
\text { decision making, persuasive writing }\end{array}$ \\
\hline Student 2 & $\begin{array}{l}\text { Pretty much all of the ones we look over in the guided writing class. I think the point about } \\
\text { employability skills is laboured a bit, but I understand why }\end{array}$ \\
\hline Student 3 & Coping with deadlines \\
\hline Student 4 & $\begin{array}{l}\text { The ones which come to mind immediately are to do with teamwork and communication, which we } \\
\text { practised on Elena's paraphrase course. I found it very helpful that we practised these skills by } \\
\text { working in pairs. Elena regularly reminded us how the course related to the skills, which was helpful }\end{array}$ \\
\hline Student 5 & $\begin{array}{c}\text { Teamwork, organisational skills, critical thinking, independence, problem solving - in other words, a } \\
\text { variety of skills that would be an asset to any company, in my opinion }\end{array}$ \\
\hline
\end{tabular}




\begin{tabular}{|c|c|}
\hline Student 6 & $\begin{array}{l}\text { I think all of the transferable employability skills have been hit across all three units. In terms of } \\
\text { Paraphrase, however, I think we have arguably hit more employability skills in that we have strict } \\
\text { deadlines and have to give feedback in a timely manner that respects our opposing pairs. It has been } \\
\text { a personal learning curve of mine to try and figure out how to get my arguments across in a cohesive } \\
\text { way to someone I may not necessarily have worked with before and to have the confidence in my } \\
\text { own suggestions and ideas. Working in a three for the first half in particular helped me develop skills } \\
\text { of making my own voice heard whilst juggling with the suggestions of two other people. More } \\
\text { generally, giving feedback in a clear, helpful manner to opposing pair has been a skill that I did not } \\
\text { possess before the start of this unit }\end{array}$ \\
\hline Student 7 & $\begin{array}{c}\text { Time management, communication (with tutors and other students on the course), teamwork, } \\
\text { adaptability (adapting to online learning and a heavier workload) }\end{array}$ \\
\hline Student 8 & Critical skills, Communicative skills, Interpersonal skills \\
\hline 9 & $\begin{array}{l}\text { I have learnt many - the main one I can think of is learning to communicate when giving feedback } \\
\text { and also when working in a group. This is something that I perhaps didn't know how to do that well } \\
\text { before this course }\end{array}$ \\
\hline Student 10 & Time management, working in a team, critical thinking \\
\hline Student 11 & \\
\hline Question 13 & What sugg \\
\hline Student 1 & $\begin{array}{l}\text { I think I will find it difficult to write a precis now, having not done it since TB1. This is tricky as I } \\
\text { know I will have to write one in the exam, so would prefer if somehow, we could do one week } \\
\text { precis, one week paraphrase rather than one term of each, so that we do them both equally all } \\
\text { throughout the way, in preparation for exams at the end }\end{array}$ \\
\hline Student 2 & \\
\hline Student 3 & \\
\hline Student 4 & $\begin{array}{l}\text { It would be useful to do something 'new' in Elena } \\
\text { about the previous week's paraphrase. I think it } \\
10-15 \text { minutes, but then do a different activit }\end{array}$ \\
\hline Student 5 & No answer \\
\hline Student 6 & $\begin{array}{l}\text { I am feeling a bit less confident in Precis as I had this last term, but I understand that this is a } \\
\text { scheduling issue that cannot be changed. In terms of the course content, I can think of absolutely } \\
\text { nothing that can help strengthen this course. } \\
\text { Every single detail is focused on developing our skills as learners whilst looking ahead to future } \\
\text { employability }\end{array}$ \\
\hline Student 7 & \\
\hline Student 8 & $\begin{array}{r}\text { Asking for both versions of the translation so that c } \\
\text { translatic }\end{array}$ \\
\hline & I'll be very honest, I'm not entirely sure how to improve the course because it is alre \\
\hline Student 10 & $\begin{array}{l}\text { Although I enjoy the E-R paraphrase class I'm not sure that learning to translate/paraphrase into } \\
\text { Russian is a very useful skill for the future as we'll never be employed to do that as non-native } \\
\text { speakers }\end{array}$ \\
\hline Student 11 & $\begin{array}{l}\text { Maybe using a broader range of resources - there were some videos which were good but maybe } \\
\text { poetry, podcasts and longer topical films could be a good thing to explore }\end{array}$ \\
\hline Question 14 & \\
\hline Student 1 & $\begin{array}{l}\text { The paraphrase class is very useful, but so very time-consuming. With all my other classes and } \\
\text { modules, I sometimes struggle to get everything done, as I feel I have to make paraphrase a priority, } \\
\text { meaning I skip work for other classes. It would be useful if the texts were perhaps shorter, or if we } \\
\text { had longer to submit each piece of work }\end{array}$ \\
\hline Student 2 & $\begin{array}{l}\text { The Russian department is ahead of the other language departments, who are still following the same } \\
\text { 'integrated skills' formula. I hope that feedback is shared around, and the departments can learn from } \\
\text { each other }\end{array}$ \\
\hline & No other comments \\
\hline Student 4 & $\begin{array}{l}\text { Overall, I'm very happy with all } 3 \text { elements of this course. Especially considering the challenging } \\
\text { circumstances created by COVID, I've been very impressed with all my Russian written language } \\
\text { teaching this year. Thank you very much! }\end{array}$ \\
\hline
\end{tabular}


Elena McNeilly. Redesigning an Undergraduate Russian Language Unit: Reflections on Aligning...

\begin{tabular}{||c||c|c|}
\hline Student 5 & No other comments \\
\hline Student 6 & $\begin{array}{c}\text { I really cannot emphasise how much I appreciate the Russian department and how tight a ship } \\
\text { Elena runs. The fact that the Russian department structures the language units around separate skills } \\
\text { is phenomenal, not to mention that Political \& Economic Russian is an absolute lifesaver in terms of } \\
\text { getting in extra practice. I really cannot express how much this course is like gold dust and the } \\
\text { Russian department goes above and beyond in every sense of the word. The support that Elena, } \\
\text { Yelena \& Ilona provide is beyond anything I have ever experienced at Bristol, and I will miss this } \\
\text { little family so much }\end{array}$ \\
\hline Student 7 & No other comments. \\
\hline Student 8 & No other comments. \\
\hline Student 9 & $\begin{array}{c}\text { Overall, I have loved every minute of my Russian studies at Bristol, even this year with the } \\
\text { pandemic the Russian department has been absolutely incredible, and I honestly couldn't thank you } \\
\text { enough for everything you've done for us students. The absolute best department - I am certainly } \\
\text { going to miss it! }\end{array}$ \\
\hline Student 10 & No, I'm really enjoying our last year with the department! \\
\hline Student 11 & It was overall very enjoyable :) \\
\hline \hline
\end{tabular}

\section{Conclusions}

The analysis of student responses to the survey questions confirms that, overall, the students are satisfied with the structure of the new curriculum as well as with the teaching methods and the assessment format of the unit.

The final-year curriculum has been redesigned in a way that students' learning experience and departmental teaching practices are linked not only to the preparation for the final exams but also to the development of transferable skills sought by employers.

The analysis of the survey indicates that students realise that in addition to advanced language and analytical skills in Russian they have indeed developed transferable employability skills and attributes [7]. It is therefore reasonable to conclude that Priority 3 "Design, develop and deliver a 'Bristol Futures' curriculum that will ensure all students acquire the knowledge, skills and understanding needed to equip them for success within a rapidly changing world of work", and specifically Action 3.1 of the UoB Education strategy, have been addressed in the redesigned curriculum, and, consequently, in our teaching practice: "We will provide a Bristol Skills Framework against which students can assess their skills development, evidencing and recording their personal development in order to foster and demonstrate a rounded set of graduate attributes. We will provide academic study skill resources to support students to successfully transition to study at University and progress through their academic programmes." [6].

Responses indicate that certain structural nuances (e.g., the timetabling/sequence of the individual modules) needed rethinking. Students' constructive suggestions have been considered in preparation for the next academic year. This aspect of quality assurance fits well in the Quality Assurance Agency's (QAA) findings on good practice in use of student feedback: “...the priority given to the role of students in contributing to quality assurance and enhancement; this can be achieved through various mechanisms, such as student representation and surveys" [9].

Overall, in answer to the questions set out at the start of this paper, it is reasonable to conclude that the teaching practice, learning, and assessment within the new unit are constructively aligned. Our findings also confirm that departmental practice is in line with the UoB Education Strategy envisaging "course design and assessment practices that challenge our students and so empower them to achieve their full potential" [6].

Moreover, the survey results indicate that students have adapted well to the challenges caused by the Covid-19 pandemic as they have been fully engaged in their learning process within the blended and online delivery of the language teaching programme. 


\section{Ethics Approval Statement}

This project gained Ethics Approval on $15^{\text {th }}$ March 2021.

The research included in this paper has been conducted with full compliance of research ethics norms, and more specifically with the codes and practices established in the British Educational Research Association (BERA) Ethics Guidelines, and appropriate University of Bristol Faculty Ethics Guidelines.

This research does not deal with sensitive topics, has not been conducted using covert methods, and all participants are over the age of 18. Participants have given informed consent for their data to be used for the purposes of this research. Participants had the right to withdraw without consequence and their confidentiality has been protected by making their responses anonymous.

\section{References}

1. University of Bristol. (2020). Unit and programme catalogue 2020/21

2. Biggs, J. (2003). Teaching for Quality Learning at University. The Society for Research into Higher Education \& Open University Press.

3. Norton, L. (2007). Using assessment to promote quality learning in higher education. Learning, Teaching and Assessing in Higher Education. Developing Reflective Practice. Edited by Campbell, A., Norton, L. Learning Matters Ltd.

4. Wride, M. (2017). Guide to Peer-Assessment, Academic Practice; University of Dublin, Trinity College.

5. Lea, M.R. (2004). Academic literacies: A pedagogy for course design. Studies in Higher Education, 29:6, 739756.

6. University of Bristol. (2017). Education Strategy 2017-23. education-strategy-2017-23.pdf (bristol.ac.uk)

7. Anisimova, A., McNeilly, E. (2021) Ways to develop employability skills in teaching translation to final-year students. Professional Discourse and Communication, Vol 3, No 1, 75-84.

8. Brennan, J., Williams, R. (2004). Collecting and using student feedback. A guide to good practice. Learning and Teaching Support Network (LTSN)

9. The Quality Assurance Agency for Higher Education. (2013). Responding to feedback from students. Guidance about providing information for students. The Quality Assurance Agency for Higher Education (qaa.ac.uk)

Elena McNeilly, Fellow of the Higher Education Academy (FHEA). Senior Lecturer in Russian. Language Director (Russian and Czech Studies). School of Modern Languages. Faculty of Arts. University of Bristol (17 Woodland Road, Bristol, BS8 1TE)

E-mail: elena.mcneilly@bristol.ac.uk 